СФІМОВА Г.В.

Доктор економічних наук, професор

Завідувач кафедри

Національний університет кораблебудування імені адмірала Макарова

Пр-т Героїв України, 19, Миколаїв, Україна, 54025

E-mail: hanna.efimova@nuos.edu.ua

ORCID: 0000-0001-5271-2913

МАРУЩАК C.В.

Кандидат економічних наук

Доцентт

Національний університет кораблебудування імені адмірала Макарова

Пр-т Героїв України, 19, Миколаїв, Україна, 54025

E-mail: svitlana.marushchak@nuos.edu.ua

ORCID: 0000-0002-0760-4427

\title{
ПАЩЕНКО О.В.
}

Кандидат економічних наук, дочент

Доцент

Національний університет кораблебудування імені адмірала Макарова

Пр-т Героїв України, 19, Миколаїв, Украӥна, 54025

E-mail: oleksiy.pashchenko@nuos.edu.ua

ORCID: 0000-0001-9513-8632

\section{ПЛАНУВАННЯ РОЗВИТКУ МОРЕГОСПОДАРЬСКОГО ПІДПРИЕМСТВА НА ОСНОВІ РІВНЯ ЙОГО ЕКОНОМІЧНОЇ БЕЗПЕКИ}

Актуальність. Важливою умовою забезпечення розвитку підприємств морегосподарського комплексу $\epsilon$ формування ефективної стратегї. Динамічність та невизначеність середовища, в якому функціонують підприємства, викликають необхідність враховувати рівень їх економічної безпеки при прийнятті рімень щзоо вибору стратегії розвитку.

Мета та завдання. Метою статті є розробка методичних рекомендацій щзодо вибору стратегії розвитку морегосподарського підприсмства на основі оцінки рівня його економічно безпеки.

Результати. Розглянуто системний підхід до управління економічною безпекою підприємства. Визначено зміст стратегічного планування розвитку морегосподарського підприємства та взаємозв'язок із рівнем економічної безпеки. Встановлено якісні параметри використання корпоративних ресурсів у поєднанні $з$ організаційно-функиіональною структурою та взаємозв'язками структурних підрозділів, а також деякі кількісні вказівки щуодо забезпечення функціональних складових та рівня економічної безпеки компаній в цүілому. Запропоновано виділяти чотири стратегічні напрямки управління економічною безпекою підприємств в сфері морегосподарювання. Для реалізачії обраної стратегії визначено механізм управління економічною безпекою компаній морського комплексу, його елементи, схему їх дї та взаємодіі. Встановлено пріоритети вибору стратегї розвитку підприємства в залежності від рівня економічної безпеки. Запропоновано використання сиенарного підходу для планування економічної безпеки на основі моніторингу ризиків та загроз поточної діяльності морегосподарьского підприємства.

Висновки. Запропонований підхід дозволяе охарактеризувати умови морегосподарювання за рівнем безпеки і на основі иієї інформації визначити пріоритетні напрямки стратегічного планування економічної безпеки підприємств. За умов ефективного використання корпоративних ресурсів на підприємствах створюватимуться сприятливі умови для досягнення иілей бізнесу, своєчасного виявлення $і$ максимального послаблення впливу різного роду небезпек $і$ загроз в умовах конкуренції та господарського ризику, а відтак забезпечуватиметься функціонування та подальший розвиток морегоподарського комплексу.

Ключові слова: стратегія, морегосподарювання, розвиток підприємства, корпоративні ресурси, небезпеки, загрози, ризик, безпека, стратегічний пріоритет.

IEFIMOVA GANNA

Doctor of Economic Science, Professor

Head of Department 
Admiral Makarov National University of Shipbuilding

Heroiv Ukrainy av., 9, Mykolayv, Ukraine, 54025

E-mail: hanna.efimova@nuos.edu.ua

ORCID: 0000-0001-5271-2913

MARUSHCHAK SVITLANA

Candidate of Economic Science

Associated Professor

Admiral Makarov National University of Shipbuilding

Heroiv Ukrainy av., 9, Mykolayv, Ukraine, 54025

E-mail: svitlana.marushchak@nuos.edu.ua

ORCID: 0000-0002-0760-4427

PASHCHENKO OLEKSIY

Candidate of Economic Science, Associated Professor

Associated Professor

Admiral Makarov National University of Shipbuilding

Heroiv Ukrainy av., 9, Mykolayv, Ukraine, 54025

E-mail: oleksiy.pashchenko@nuos.edu.ua

ORCID: 0000-0001-9513-8632

\section{PLANNING THE MARITIME COMPANY'S DEVELOPMENT ON THE BASIS OF ITS ECONOMIC SECURITY LEVEL}

Topicality. An important condition for ensuring the development of the maritime complex companies is the formation of an effective strategy. The dynamism and uncertainty of the environment in which companies operate, necessitate taking into account the level of their economic security when making decisions about the choice of development strategy.

Aim and tasks. The purpose of the article is to develop guidelines for choosing a strategy for the development of a maritime company based on an assessment of its economic security.

Research results. The system approach to management of the company's economic safety is considered. The content of strategic planning for the maritime company development and its correlation with the level of economic security are determined. Qualitative parameters of the corporate resources use in combination with the organizational and functional structure and relationships of structural units, as well as some quantitative guidelines for ensuring the functional components and the level of economic security of companies in general. To identify four strategic areas of the company's economic security management in the field of maritime management is proposed. The mechanism of the maritime complex companies' economic security management, its elements, the scheme of their action and interaction are determined to implement the chosen strategy. The priorities for choosing the strategy of the company's development depending on the level of economic security are specified. The use of a scenario approach for economic security planning based on monitoring the risks and threats of the current activities of the maritime companies is proposed.

Conclusion. The proposed approach allows characterizing the conditions of maritime management by the level of safety and on the basis of this information to determine the priority areas of strategic planning of the company's economic security. Under the conditions of efficient use of corporate resources at company, favourable conditions will be created for achieving business goals, timely detection and maximum mitigation of various dangers and threats in conditions of competition and economic risk, and thus - will ensure the functioning and further development of the maritime complex.

Keywords: strategy, marine, company development, corporate resources, dangers, threats, risk, security, strategic priority.

Problem statement and its connection with important scientific and practical tasks. Economic security is an institution, both economic and political, built into the market economy, and performs not only the functions of ensuring the effective operation of its subsystems and units, the formation and maintenance of long-term company's competitiveness in the market, but also the protection of their economic interests, when the economy is functioning inefficiently. The maritime complex companies are in a situation of uncertainty, unpredictability, namely the constant dynamics of both internal and external economic conditions: political, macroeconomic, environmental, legal, and make risky decisions in conditions of fierce competition, seek prevention, weakening or protection from existing or projected dangers or threats.

The maritime complex companies independently determine their economic policy, form a portfolio of orders, organize the production and sale of products, are fully responsible for the results of economic 
activity. These factors, of course, actualize the problem of ensuring economic security of development, which is possible only with a systematic approach to solving this problem.

The scientific task is to improve the approach to the alternative of strategy for the company economic security on the basis of the its level diagnostics results in the form of recommendations for choosing priority areas, which will improve the quality of business decisions as a prerequisite for further effective development. The practical aspect is to develop recommendations for strategic planning of the maritime company's development in order to form a system of economic security to create conditions conducive to the successful operation and further development.

Analysis of recent publications on the problem. The results of the literature sources analysis on this issue showed that currently developed economic, legal and institutional principles of guaranteeing company's economic security, outlined the main principles and directions of improving the company's economic security $[1,2,3,4,5]$, developed the theory of financial stability $[6,7,8]$, investigated the need, causes and functions of the company's economic security $[3,9,10,11]$, further developed the theory of economic risks in business and the theory of crisis management, developed general approaches to analysis and evaluation of functional components of company's economic security $[12,13,14,15,16,17]$. A number of studies are devoted to the study of maritime issues in the context of ensuring the competitiveness and company's economic security in this complex [18, 19, 20, 21, 22,23,24].

Allocation of previously unsolved parts of the general problem. Further research is needed on planning the maritime complex company's development depending on the level of its economic security. Namely, the study of the essence, structure and qualitative features of economic security of both maritime management in general and the maritime company in particular, the development of an effective approach to planning its development and the formation of the economic security concept.

Formulation of research objectives (problem statement). The purpose of the study is to develop guidelines for choosing a strategy for the maritime companies development based on an assessment of its economic security.

An outline of the main results and their justification. The concept of economic security can be represented as the absence of various dangers and threats or the availability of opportunities to prevent them, protect their interests, and prevent damage beyond the critical limit [25]. The desired can be achieved by building an economic security system, which will create conditions for unprofitable companies' activities, its property preservation, prevention of secrets disclosure, intellectual property preservation, highly qualified personnel attraction, their training and career growth, etc. In the case when under these conditions they ensure the achievement of the goals of their operation and production of the following, is defined as development. That is, the state of the enterprise, when the corporate resources of the company - land, capital, human resources, entrepreneurial skills of managers, information, intellectual property, technology, etc. - are used primarily for development, not just to prevent dangers and threats.

The enterprises of the maritime complex independently determine their economic policy, form an orders portfolio, organize the production and sale of products, are fully responsible for the results of economic activity. These factors, of course, actualize the problem of ensuring economic security of development, which is possible only with a systematic approach to solving this problem.

A system approach to the formation of a mechanism for managing the maritime complex companies' economic security implies the need to take into account all the real conditions of its activities, and the mechanism itself must have clearly defined elements, the scheme of their action and interaction [26]. The structure of economic security management consists of certain stages, sequential or in some cases simultaneous implementation of which provides favourable conditions for the development of maritime enterprises.

The most important stage of ensuring the maritime complex companies' economic security is strategic planning and forecasting of its level. This stage includes the development of a strategic plan to ensure the companies' economic security. In this document, it is necessary to set the qualitative parameters of the corporate resources use in combination with the organizational and functional structure and relationships of structural units, as well as some quantitative guidelines for ensuring the functional components and the level of companies' economic security as a whole [27, 28].

Companies' economic security strategies are different in their content. There are three types of security strategies:

- 1 forecasting strategy is a strategy focused on forecasting, early detection of dangers and threats, purposeful study of economic and criminogenic situations both within the company and in the environment. 
Specialists assigned to solve this problem, created units and security services provide an opportunity to consciously and purposefully work to create favorable conditions for business;

- 2 response strategy is a strategy related to the need to react suddenly to real threats to production activities, property, personnel, etc. That is, in this case the principle of "threat-reflection" applies. Units, services, forces, and resources created (often hastily) to address this challenge can mitigate or prevent the impact of threats; at the same time the company can be damaged;

- 3 compensation strategy is an economic security strategy aimed at compensation (restoration) for damage. This strategy can be considered acceptable only when the damage is done, or when it is not possible to implement strategies of the first or second type.

According to the principles of economic security, the application of each of the identified strategies in its pure form is not acceptable for the maritime complex companies. It is advisable to rationally combine the three identified methods of action in the order of their definition. We propose to identify the following four strategic areas of companies' economic security management in the field of maritime management:

- strategy of focusing on improving the economic security level;

- strategy of priority response to threats;

- strategy of maintaining the economic security level;

- strategy of increasing the economic security level.

The company's choice of strategic direction of economic security management should be determined by its level (Table 1).

Table 1

Recommendations for choosing a strategy for managing the company's economic security *

\begin{tabular}{|c|c|}
\hline $\begin{array}{l}\text { Level of the company's economic } \\
\text { security }\end{array}$ & $\begin{array}{l}\text { Kind of a strategy for managing the company's economic } \\
\text { security }\end{array}$ \\
\hline Very low & focusing on improving the company's economic security level \\
\hline Low & priority response to threats \\
\hline Average & $\begin{array}{l}\text { improving or maintaining the company's economic security } \\
\text { level }\end{array}$ \\
\hline High & $\begin{array}{l}\text { improving or maintaining the company's economic security } \\
\text { level }\end{array}$ \\
\hline Very high & maintaining the company's economic security level \\
\hline
\end{tabular}

For different current levels of maritime company's economic security, the priority of choosing a strategy for further development is defined in table. 2.

Table 2

Priorities for choosing the overall strategy of company's development *

\begin{tabular}{|l|l|}
\hline $\begin{array}{c}\text { The value of the variable } \\
\text { «The company's economic } \\
\text { security level» }\end{array}$ & \multicolumn{1}{c|}{ Priority areas for choosing the company's economic security strategies } \\
\hline «Extreme danger» & $\begin{array}{l}\text { The company's strategy is to increase security. Because, this company's } \\
\text { economic security level is determined by the low level of indicators, and } \\
\text { hence the low efficiency level. In this case, the primary task of the company } \\
\text { will be to increase the efficiency level. There will be a lack of company } \\
\text { resources to prevent threats. Therefore, the company will focus on the } \\
\text { compensation strategy. The other two strategies will be applied as far as the } \\
\text { company can. }\end{array}$ \\
\hline «Danger» & $\begin{array}{l}\text { The company's strategy is to increase security. This company's economic } \\
\text { security level is not critical, but it cannot satisfy the company. In this case, its } \\
\text { task will also be to increase the efficiency level, use of resources. The } \\
\text { company has more opportunities to predict and respond to threats, but the } \\
\text { priority will remain the strategy of compensation. }\end{array}$ \\
\hline «Average level of security»» & $\begin{array}{l}\text { The company's strategy is to increase security by increasing resources to } \\
\text { respond to threats and forecast them. Planning the company's safe } \\
\text { development is focused on the strategy «Absolute security». }\end{array}$ \\
\hline
\end{tabular}


Table 2 continuation

\begin{tabular}{|l|l|}
\hline \multirow{2}{*}{ «Relative security» } & $\begin{array}{l}\text { The company's strategy is at least to maintain such the company's economic } \\
\text { security level, and at most - a predominant response to possible threats to its } \\
\text { development. Planning the company's safe development is focused on the } \\
\text { strategy of «Absolute security». }\end{array}$ \\
\hline «Absolute security» & $\begin{array}{l}\text { The company's strategy is to maintain this state. Its actions should be aimed } \\
\text { at timely detection, that is forecasting of possible threats and their } \\
\text { neutralization. } \\
\text { Two other strategies can be used in case of inability to predict or incorrect } \\
\text { forecast of the situation. In addition, the response strategy is planned in case } \\
\text { of threats, the consequences of which the company is able to neutralize } \\
\text { immediately and it is not associated with significant financial costs, the } \\
\text { likelihood of threats is low, and the implementation of preventive measures } \\
\text { is associated with significant costs, that is they are impractical. }\end{array}$ \\
\hline
\end{tabular}

* author's development

- if the company's economic security level is defined as "Very low", the efforts of the company in terms of managing safe development should be aimed at improving the security level, which should be one of the priority areas of the company development. Choosing an company is a strategy of focusing on increasing the company's economic security level;

- if the company's economic security level is defined as "Low", the efforts of the company in terms of managing the company safe development should also be aimed at improving its security level. However, in this case, to achieve the average company's economic security level for it will be much easier, which means less resource costs to achieve the desired. The average company's economic security level is the primary and minimum task for the company. The company must choose a strategy to increase the level of development security;

- if the level of the company's economic security is defined as "Average", the efforts of the company in terms of managing the safe development of the company should be aimed at improving the level of security or maintaining the achieved depending on the enterprise development goals and available resources. In this case, the company has an alternative. The company has a choice between two strategies: a security strategy and a retention strategy. The choice will be decided by the priorities of the company itself;

- if the level of the company's economic security is defined as "High", the efforts of the enterprise in terms of managing the safe development of the company should be aimed either at increasing the development security level with resources and long-term development plans, or at maintaining the existing level. In this case, a higher priority in the strategy of managing the company's economic security should be to maintain the achieved level. The company, as in the previous case, has a choice between two strategies;

- if the level of the company's economic security is defined as "Very high", the efforts of the company in terms of managing the company's safe development should be aimed solely at maintaining the achieved level. This situation may be characterized by lower costs of material resources, but higher costs of intellectual resources in terms of highly qualified specialists.

For the maritime complex companies of the Mykolaiv region the assessment of economic safety level by the author's method based on fuzzy logic was carried out. In the table. 3 gives a linguistic assessment of these company's economic security levels.

Table 3

Conclusions on the level of the maritime complex company's economic security of the Mykolaiv region for 2020 on the basis of a linguistic assessment *

\begin{tabular}{|c|c|}
\hline Companies & Conclusion on the level of economic security \\
\hline Shipbuilding and shiprepair plant "Nibulon" & $\begin{array}{l}\text { Very high level of economic security with a probability } \\
100 \%\end{array}$ \\
\hline PJSC Mykolaiv Shipbuilding plant "Ocean" & $\begin{array}{l}\text { Average level of economic security with a probability } \\
32 \% \text {, or low with a probability } 68 \%\end{array}$ \\
\hline LLC "Artel" Ltd. & $\begin{array}{l}\text { High level of economic security with a probability } \\
100 \%\end{array}$ \\
\hline LLC “Maritek” Ltd. & $\begin{array}{l}\text { High level of economic security with a probability } \\
100 \%\end{array}$ \\
\hline
\end{tabular}


Table 3 continuation

\begin{tabular}{|c|c|}
\hline LLC “Chornomorska yakhtena verf” & $\begin{array}{c}\text { High level of economic security with a probability } 73 \% \text {, } \\
\text { or average with a probability } 27 \%\end{array}$ \\
\hline $\begin{array}{l}\text { LLC Shipbuilding and shiprepair company } \\
\text { "Mykolaivska Verf" }\end{array}$ & $\begin{array}{l}\text { Average level of economic security with a probability } \\
100 \%\end{array}$ \\
\hline LLC "Magistral-yug” & $\begin{array}{l}\text { High level of economic security with a probability } 39 \% \text {, } \\
\text { or average with a probability } 61 \%\end{array}$ \\
\hline LLC "Yugsudoremont" & $\begin{array}{l}\text { Average level of economic security with a probability } \\
100 \%\end{array}$ \\
\hline $\begin{array}{c}\text { Mykolaiv multiservice company LLC «Marine } \\
\text { Design Engineering Mykolaiv» }\end{array}$ & $\begin{array}{l}\text { Very high level of economic security with a probability } \\
100 \%\end{array}$ \\
\hline Branch "Delta-lotsman" of the SE AMPU & $\begin{array}{l}\text { High level of economic security with a probability } 50 \% \text {, } \\
\text { or average with a probability } 50 \%\end{array}$ \\
\hline SE Mykolaiv Sea Commercial Port & $\begin{array}{l}\text { Average level of economic security with a probability } \\
100 \%\end{array}$ \\
\hline LLC Nika-Tera Sea Specialized Port & $\begin{array}{l}\text { High level of economic security with a probability } \\
100 \%\end{array}$ \\
\hline SE Stevedoring Company “Olbia" & $\begin{array}{l}\text { Average level of economic security with a probability } \\
100 \%\end{array}$ \\
\hline LLC MP "Terminal-Ukrkharzhozbutsyrovyna" & $\begin{array}{c}\text { Average level of economic security with a probability } \\
99 \% \text {, or low with a probability } 1 \%\end{array}$ \\
\hline LLC “EVERI” & $\begin{array}{c}\text { High level of economic security with a probability } 95 \% \text {, } \\
\text { or average with a probability } 5 \%\end{array}$ \\
\hline
\end{tabular}

* calculated by the authors

For maritime enterprises of the Mykolaiv region, recommendations for the choice of development strategy are presented in table. 4.

Table 4

The recommended development strategy of the maritime companies of the Mykolaiv region *

\begin{tabular}{|c|c|}
\hline Companies & $\begin{array}{l}\text { Recommendations for choosing a strategy } \\
\text { based on an assessment of the economic } \\
\text { security level }\end{array}$ \\
\hline Shipbuilding and shiprepair plant "Nibulon" & \multirow{2}{*}{$\begin{array}{l}\text { maintaining the level of the company's } \\
\text { economic security }\end{array}$} \\
\hline $\begin{array}{c}\text { Mykolaiv multiservice company LLC «Marine Design } \\
\text { Engineering Mykolaiv» }\end{array}$ & \\
\hline LLC "Artel" Ltd. & \multirow{12}{*}{$\begin{array}{l}\text { improving or maintaining the level of the } \\
\text { company's economic security }\end{array}$} \\
\hline LLC “Maritek" Ltd. & \\
\hline LLC "Chornomorska yakhtena verf" & \\
\hline $\begin{array}{l}\text { LLC Shipbuilding and shiprepair company "Mykolaivska } \\
\text { Verf" }\end{array}$ & \\
\hline LLC “Magistral-yug” & \\
\hline LLC "Yugsudoremont" & \\
\hline Branch "Delta-lotsman" of the SE AMPU & \\
\hline SE Mykolaiv Sea Commercial Port & \\
\hline LLC Nika-Tera Sea Specialized Port & \\
\hline SE Stevedoring Company "Olbia" & \\
\hline LLC MP "Terminal-Ukrkharzhozbutsyrovyna" & \\
\hline LLC "EVERI" & \\
\hline PJSC Mykolaiv Shipbuilding plant "Ocean" & $\begin{array}{l}\text { priority response to threats and improving } \\
\text { the level of the company's economic security }\end{array}$ \\
\hline
\end{tabular}

The sequence of planning the company's economic security includes the development of strategic plans for the company, the current tactical planning of company's economic security, which is based on the 
results of assessing the its security level $[29,30]$. The analysis of the company's economic security level is carried out on the basis of a measures efficiency assessment for prevention of losses as a result of threats realization and calculation of functional and aggregate criteria of company's economic safety.

The current planning of measures for the company's economic security is based on the development of several alternative scenarios and the calculation of the total criterion values of company's economic security and other indicators for each of them [31]. Evaluation of development scenarios makes it possible to choose the best option, the analysis results of which form the basis for the development of operational recommendations for the current planning of company's economic security. They are characterized by specific short-term measures to neutralize certain threats, contribute to the normal organization of the company's current activities, and take the form of specific tasks to be performed.

In the process of carrying out the company's activities monitoring of threats and dangers is performed - qualitative analysis of company's economic security, the economic security level is assessed in quantitative terms as a whole and in terms of functional components. Taking into account the received information, which is constantly updated and accumulated, and strategic directions of ensuring the company's economic security, the operational planning of the company's financial and economic activity is carried out, after which the practical implementation of the developed plans is executed. In the process of company's financial and economic activities, new information appears to analyze its condition. It is the basis for obtaining new indicators of the level of functional and aggregate company's economic security criteria, while analyzing their deviations from the planned values, the causes of these deviations. The obtained data are used to make recommendations for adjusting the strategic and current plans of company's financial and economic activities, operational management. Adjustment is necessary in the system of the company's economic security planning. The principles and methods of making recommendations for changes in business plans and economic security are the same. Correction of plans and processes of their implementation is necessary and possible as new features and characteristics are identified, namely taking into account any changes in the external or internal environment of the enterprise. Analysis of corporate resources is a preparatory stage for the development of a system of the company's economic security. The system of the company's economic security aims to solve the tasks set before it only when it will function, that is its integral component is the practical actions to ensure business security.

\section{Conclusions and perspectives of further research.}

Thus, the management of the maritime complex company's economic security aims to create the most favorable conditions and opportunities for companies to achieve the planned goals with efficient allocation and use of corporate resources, timely identify and minimize the impact of various dangers and threats in a volatile market economy, fierce competition in the market, growing requirements for performance, improvement of management methods and means of influencing maritime safety.

The proposed methodological approach allows to characterize the conditions of maritime management in terms of functional components and in general and on the basis of this information to determine the priority areas of strategic planning of the company's economic security. Under the conditions of efficient use of corporate resources at enterprises, favorable conditions will be created for achieving business goals, timely detection and maximum mitigation of the impact of various dangers and threats in conditions of competition and economic risk, and thus ensure the functioning and further development of the maritime complex.

\section{ЛІТЕРАТУРА}

1. Дикань В.Л., Божко К.М. Стратегия обеспечения экономической безопасности промышленных предприятий. Вісник економіки транспорту і промисловості. 2018. №63. С. 150-158.

2. Івченко Є.А Трансформації системи економічної безпеки підприємства : монографія. Сєвєродонецьк: вид-во СНУ ім. В. Даля, 2018. 420 с. URL: http://dspace.snu.edu.ua:8080/jspui/bitstream/123456789/2186/1/2018.pdf

3. Пилипенко Н.М., Кліпун А.І. Концепція економічно-безпечного розвитку підприємства в сучасних умовах господарювання. Детермінанти соціально-економічного розвитку підприємств : монографія. / за наук. ред. Н.І. Строченко, В.В. Пилипенко, О.М. Ковальова. Суми, «Сумський національний аграрний університет», 2017. Вип. 4. С.99-112.

4. Погорелов Ю.С. Забезпечення економічної безпеки підприємства та його розвиток: співвідношення процесів. Перспективи управлінської діяльності суб'єктів господарювання в контексті економічної безпеки: матеріали міжнародного форуму з безпеки (м. Черкаси, 25-27 травня 2017p.) Черкаси: вид-во ПП Чабаненко Ю.А., 2017. С.100-102. 
5. Rothaermel Frank T. Strategic Management. 4th edition. McGraw-Hill Education, 2019. 593 p.

6. Азаренкова Г.М., Майборода А.В. Особливості формування підсистеми інформаційного забезпечення системи фінансової безпеки суб’єкта господарювання. Бізнес Інформ. 2020. №1. С. 210217. URL: https://doi.org/10.32983/2222-4459-2020-1-210-217

7. Орлик О. В. Финансово-экономическая безопасность предприятия и принципы ее обеспечения. Economics and management: theory and practice: collection of scientific articles. 2014. T.2. C. 286-291.

8. Сусіденко В. Т., Сусіденко О. В. Побудова системи забезпечення фінансової безпеки торговельного підприємства. Науковий вісник Херсонського державного університету. 2017. № 22. Ч. 2. C. 39-43.

9. Головчук Ю.О., Пчелянська Г.О. Особливості формування стратегії підвищення конкурентоспроможності підприємства на основі парадигми інноваційного розвитку. Економіка та держава. 2020. №3. С. 66-70.

10. Тулуб О.М. Особливості формування та функціонування системи економічної безпеки інституцій бізнесу та підприємництва за видами економічної діяльності. Глобальні та начіональні проблеми економіки. 2017. Вип.16. URL: http://global-national.in.ua/archive/16-2017/100.pdf.

11. Поляков П. А. Роль інформаційного забезпечення в управлінні економічною безпекою підприємств машинобудування. Інфраструктура ринку. 2018. № 22. С. 99-103. URL: https://chmnu.edu.ua/wpcontent/uploads/2019/07/Polyakov-P.-A..pdf

12. Гура О.Л., Бобівський В.А. Стратегія розвитку підприємств в Україні. Економіка та держава. 2020. №5. С. 175-181.

13. Єпіфанова І.Ю. Дзюбко М.Ю. Формування стратегії розвитку підприємства в сучасних умовах. Вісник ОНУ ім. Т.Г. Шевченка. 2017. Вип.2 (55). С. 99-102.

14. Melnyk O., Todoshchuk A., Adamiv M. The Role of SocioEconomic Diagnostics in an Enterprise Management System. Baltic Journal of Economic Studies. 2018. Vol.4. №.3. P. 165-171.

15. Vereshchahina H., Pliekhanova T. Improvement of the definition of strategic planning of enterprise development. Економіка та держава. 2020. №6. С. 192-200.

16. Bondarenko S., Verbivska L., Dobrianska N., Iefimova G., Pavlova V., Mamrotska O. Management of Enterprise Innovation Costs to Ensure Economic Security. International Journal of Recent Technology and Engineering (IJRTE). Volume-8 Issue-3, September 2019. P. 5609-5613.

17. Pilipenko N.M., Pilipenko V.V. Economic security as a dynamic characteristic of an enterprise. $\begin{array}{lllll}\text { Economy and } & \text { №10. } & \text { C.338-342. } & \text { URL: }\end{array}$ http://www.economyandsociety.in.ua/journal/10_ukr/59.pdf.

18. Буркинський Б. В., Грищенко В. Ф. Чинники забезпечення економічної безпеки в процесі інноваційного розвитку підприємництва. Економічні інноваџіï. 2020. Том 22. Вип. 3(76). С. 6-29. https://doi.org/10.31520/ei.2020.22.3(76).6-29

19. Гуренко А.В., Щеникова Е.В., Свсік М.С. Дослідження сучасного потенціалу морегосподарського комплексу України. Вісник Приазовського держсавного технічного університету. 2017. №33. С. 218-224.

20. Давидюк O.О., Габ О.Г., Розвиток підприємств морського транспортного комплексу в контексті глобальної макроекономічної кон'юнктури. Інвестищії: практика та досвід. 2019. №13. C. 12-16.

21. Підвищення ефективності діяльності та конкурентоспроможності підприємств морегосподарського комплексу України: монографія / авт. кол.: Жихарєва В.В., Дубовик Н.В., Наврозова Ю.О. та ін. Одеса: Купрієнко СВ, 2016. 239 с.

22. Собкевич О.В. Ресурс морегосподарського комплексу в забезпеченні сталого розвитку малих міст і зміцненні економічної безпеки України. Наукові записки Національного університету «Острозька академія». Острог : Вид-во НУ«ОА». 2017. №5(33). С. 36-40.

23. Development potential of Ukrainian maritime enterprises / O. Kibik, I. Khaiminova, V. Kotlubay, I. Redina, E. Belous. International Journal of Engineering \& Technology. 2018. № 7(4.3). P. 461-466.

24. Ilchenko S., Khumarova N., Maslii N., Demianchuk M., Skribans V. Instruments for ensuring the balanced development of inland waterway and maritime transport in Ukraine. Sustainable, Circular Management and Environmental Engineering: International Conference. (Odesa, April 16, 2021). Odesa (Ukraine), 2021. T. 255. Article Number 01021. DOI: https://doi.org/10.1051/e3sconf/202125501021

25. Соломіна Г. В. Забезпечення фінансово-економічної безпеки підприємництва : навч. посіб. Дніпро : Дніпропетровський державний університет внутрішніх справ, 2018. 234 с. 
26. Лебедко С.А. Формування механізму забезпечення економічної безпеки транспортних підприємств. Економіка та держава: міжнародний науково-практичний журнал. 2017. №8. С. 89-94. URL: http://nbuv.gov.ua/UJRN/ecde_2017_8_23

27. Гудзь О.І. Стратегія розвитку підприємства: сутність та класифікація. Економіка $i$ суспільство. 2018. №8. С. 346-352.

28. Костецька Н.I. Стратегічне планування діяльності підприємств: теоретичні аспекти. Інновачійна економіка. 2020. №7-8. С. 65-71.

29. Костецька Н.І. Передумови впровадження системи планування діяльності підприємства. Сталий розвиток економіки. 2019. № 2(43). С. 78-84.

30. Отенко В.І., Погорелов Ю.С. Модель розвитку підприємства як основа його стратегічного вибору. Бізнес Інформ. 2017. № 11. С. 448-453.

31. Barney Jay B., Hesterly William S. (eds.) Strategic Management and Competitive Advantage: Concepts and Cases 6th edition. Pearson Education, 2019. 2200 p.

\section{REFERENCES}

1. Dykan V.L., Bozhko K.M. (2018) Stratehyya obespechenyya ekonomycheskoy bezopasnosty promyshlennykh predpryyatyy. [Strategy for ensuring the economic security of industrial enterprises] Bulletin of Transport Economics and Industry. №63. P. 150-158. [in Ukrainian]

2. Ivchenko E.A (2018) Transformatsiyi systemy ekonomichnoyi bezpeky pidpryyemstva: monohrafiya. [Transformations of the economic security of the enterprise: a monograph] Severodonetsk: published by SNU. V. Dalia. 420p. URL: http://dspace.snu.edu.ua:8080 /jspui/bitstream/123456789/2186/1/2018.pdf [in Ukrainian]

3. Pylypenko N.M., Klipun A.I. (2017) Kontseptsiia ekonomichno-bezpechnoho rozvytku pidpryiemstva v suchasnykh umovakh hospodariuvannia. Determinanty sotsialno-ekonomichnoho rozvytku pidpryiemstv : monohrafiia. za nauk. red. N.I. Strochenko, V.V. Pylypenko, O.M. Kovalov [Concept of economic and security-free development of the enterprise in modern economic conditions. Determinants sotsialno-ekonomichnoho rozvytku pidpryiemstv: monohrafiia. sci. ed. N.I. Strochenko, V.V. Pylypenko, O.M. Kovalov] Sumy, "Sumy National Agrarian University" Issue. 4. P.99-112 [in Ukrainian]

4. Pohorelov Y.S. (2017) Zabezpechennia ekonomichnoi bezpeky pidpryiemstva ta yoho rozvytok: spivvidnoshennia protsesiv. Perspektyvy upravlinskoi diialnosti subiektiv hospodariuvannia $\mathrm{v}$ konteksti ekonomichnoi bezpeky: materialy mizhnarodnoho forumu $\mathrm{z}$ bezpeky [Ensuring the economic security of the enterprise and its development: the ratio of processes. Prospects of management activities of economic entities in the context of economic security: materials of the international security forum] Cherkasy: vyd-vo PP Chabanenko Y.A. P.100-102. [in Ukrainian]

5. Rothaermel Frank T. (2019) Strategic Management. 4th edition. McGraw-Hill Education. 593 p. [in English]

6. Azarenkova, H.M., Maiboroda, A.V. (2020) Osoblivosti formuvannya pidsistemi informaczijnogo zabezpechennya sistemi finansovoyi bezpeki subyekta gospodaryuvannya. [Features of the Formation of $a$ Subsystem of Information Provision of the Enterprise's Financial Security System] - Business Inform 1: P. 210-217. URL: https://doi.org/10.32983/2222-4459-2020-1-210-217 [in Ukrainian]

7. Orlik O. V. (2014) Finansovo-ekonomicheskaya bezopasnost predpriyatiya i princzipy ee obespecheniya. [Financial and economic security of the enterprise and principles of its provision] Economics and management: theory and practice: collection of scientific articles. V.2. P. 286-291. [in Russian]

8. Susidenko V. T., Susidenko O. V. (2017) Pobudova systemy zabezpechennia finansovoi bezpeky torhovelnoho pidpryiemstva. [Construction of a system for ensuring the financial security of a commercial enterprise] Scientific Bulletin of Kherson State University № 22. V. 2. P. 39-43 [in Ukrainian]

9. Holovchuk Y., Pchelianska G. (2020) Osoblivosti formuvannya strategiyi pidvishhennya konkurentospromozhnosti pidpriyemstva na osnovi paradigmi innovaczijnogo rozvitku [Strategies formation pecularities of enterprise competitiveness incrieasing on the basis of innovation devlopment paradigm] Economy and state. №3. P. 66-70. [in Ukrainian]

10. Tulub O.M. (2017) Osoblyvosti formuvannia ta funktsionuvannia systemy ekonomichnoi bezpeky instytutsii biznesu ta pidpryiemnytstva za vydamy ekonomichnoi diialnosti. [Features of formation and functioning of the system of economic security of business and entrepreneurship institutions by types of economic activity] Global and national economic problems Issue 16 URL: http://globalnational.in.ua/archive/16-2017/100.pdf. [in Ukrainian] 
11. Poliakov P. A. (2018) Rol informatsiinoho zabezpechennia v upravlinni ekonomichnoiu bezpekoiu pidpryiemstv mashynobuduvannia. Infrastruktura rynku. [The role of information support in the management of economic security of machine-building enterprises] Market infrastructure № 22. Р. 99-103. URL:https://chmnu.edu.ua/ wpcontent /uploads/2019/07/Polyakov-P.-A.pdf [in Ukrainian]

12. Hura O.L., Bobivskyi V.A. (2020) Stratehiia rozvytku pidpryiemstv v Ukraini. [Enterprise development strategy in Ukraine] Economy and state. №5. P. 175-181. [in Ukrainian]

13. Yepifanova I.U. Dzyubko M.U. (2017) Formuvannya stratehiyi rozvytku pidpryyemstva v suchasnykh umovakh. [Formation of enterprise development strategy in modern conditions] Bulletin of ONU named after T.G. Shevchenko. Issue.2 (55). P. 99-102. [in Ukrainian]

14. Melnyk O., Todoshchuk A., Adamiv M. (2018) The Role of SocioEconomic Diagnostics in an Enterprise Management System. Baltic Journal of Economic Studies. Vol.4. №.3. P. 165-171. [in English]

15. Vereshchahina H., Pliekhanova T. (2020) Improvement of the definition of strategic planning of enterprise development. Economy and state. №6. p. 192-200. [in English]

16. Bondarenko S., Verbivska L., Dobrianska N., Iefimova G., Pavlova V., Mamrotska O. (2019) Management of Enterprise Innovation Costs to Ensure Economic Security. International Journal of Recent Technology and Engineering (IJRTE). Volume-8 Issue-3, September P. 5609-5613. [in English]

17. Pilipenko N.M., Pilipenko V.V. (2017) Economic security as a dynamic characteristic of an $\begin{array}{lllll}\text { enterprise. } & \text { Economy } & \text { №10. } & \text { P.338-342. } & \text { URL: }\end{array}$ http://www.economyandsociety.in.ua/journal/10_ukr/59.pdf. [in English]

18. Burkinsky B.V., Grishchenko V.F. (2020) Factors of economic security in the process of innovative development of entrepreneurship [Chynnyky zabezpechennya ekonomichnoyi bezpeky v protsesi innovatsiynoho rozvytku pidpryyemnytstva] Economic innovations. V. 22. Iss. 3(76). P. 6-29. https://doi.org/10.31520/ei.2020.22.3(76).6-29 [in Ukrainian]

19. Hurenko A.V., Shchenykova E.V., Yevsik M.S. (2017) Doslidzhennia suchasnoho potentsialu morehospodarskoho kompleksu Ukrainy. [Research of modern potential of the maritime complex of Ukraine] Bulletin of Priazovsky State Technical University. №33. P. 218-224 [in Ukrainian]

20. Davydiuk O.O., Hab O.H. (2019) Rozvytok pidpryiemstv morskoho transportnoho kompleksu v konteksti hlobalnoi makroekonomichnoi koniunktury. [Development of enterprises of the maritime transport complex in the context of the global macroeconomic situation] Investments: practice and experience. №13. P. 12-16. [in Ukrainian]

21. Zhykharieva V.V., Dubovyk N.V., Navrozova Y.O. ta in. (2016). Pidvyshchennia efektyvnosti diialnosti ta konkurentospromozhnosti pidpryiemstv morehospodarskoho kompleksu Ukrainy: monohrafiia [Improving the efficiency and competitiveness of enterprises of the maritime complex of Ukraine: $a$ monograph] Odesa Kupriienko SV 239p. [in Ukrainian]

22. Sobkevych O.V. (2017) Resurs morehospodarskoho kompleksu v zabezpechenni staloho rozvytku malykh mist i zmitsnenni ekonomichnoi bezpeky Ukrainy. [The resource of the maritime complex in ensuring the sustainable development of small towns and strengthening the economic security of Ukraine]. Scientific notes of the National University "Ostroh Academy". Ostrog: OU OA Publishing House №5(33). P. 36-40. [in Ukrainian].

23. Kibik O., Khaiminova I., Kotlubay V., Redina I., Belous E. (2018) Development potential of Ukrainian maritime enterprises. International Journal of Engineering \& Technology. № 7(4.3). P. 461-466. [in English]

24. Ilchenko S., Khumarova N., Maslii N., Demianchuk M., Skribans V. (2021) Instruments for ensuring the balanced development of inland waterway and maritime transport in Ukraine. Sustainable, Circular Management and Environmental Engineering: International Conference. (Odesa, April 16, 2021). T. 255. Article Number 01021. DOI: https://doi.org/10.1051/e3sconf/202125501021 [in English]

25. Solomina H. V. (2018) Zabezpechennia finansovo-ekonomichnoi bezpeky pidpryiemnytstva : navch. posib. [Ensuring financial and economic security of entrepreneurship: a textbook] Dnipro: Dnipropetrovsk State University of Internal Affairs, 234 p. [in Ukrainian]

26. Lebedko S.A. (2017) Formuvannya mekhanizmu zabezpechennya ekonomichnoyi bezpeky transportnykh pidpryyemstv. [Formation of a mechanism for ensuring the economic security of transport enterprises] Economy and State: International Scientific and Practical Journal. №8. P. 89-94. URL: http://nbuv.gov.ua/UJRN/ecde_2017_8_23 [in Ukrainian]

27. Hudz O.I. (2018) Stratehiia rozvytku pidpryiemstva: sutnist ta klasyfikatsiia [Enterprise development strategy: essence and classification] Economy and society. №8. P. 346-352. 
28. Kostetska N.I. (2020) Stratehichne planuvannya diyalnosti pidpryyemstv: teoretychni aspekty.[Strategic planning of enterprises: theoretical aspects] Innovative economy №7-8. P. 65-71. [in Ukrainian]

29. Kostetska N.I. (2019) Peredumovy vprovadzhennya systemy planuvannya diyalnosti pidpryyemstva. Stalyy rozvytok ekonomiky [Prerequisites for implementing an enterprise planning system] Sustainable economic development № 2(43). P. 78-84. [in Ukrainian]

30. Otenko V.I., Pohorelov Y.S. (2017) Model rozvytku pidpryiemstva yak osnova yoho stratehichnoho vyboru. [The model of enterprise development as the basis of its strategic choice] Business Inform № 11. P. 448-453 [in Ukrainian]

31. Barney Jay B., Hesterly William S. (eds.) (2019) Strategic Management and Competitive Advantage: Concepts and Cases 6th edition. Pearson Education. 2200 p. [in English] 